ISSN: 2146-3042

DOI: $10.25095 /$ mufad.579653

\title{
Yeşil Hastanelerde Çevre Maliyetleri ve Maliyet Hesaplarının Sinıflandırılması*
}

\author{
Vedat EKERGILL**
}

Ali Bertan SAVAŞ ${ }^{* * *}$

\begin{abstract}
ÖZET
Dünya'da yaşanan hızlı nüfus artışı, tüketici eğilimleri ve doğaya karlşan zehirli atıklar, kirliliğin ve çevreye yayılan sera gazlarının hızla artmasına neden olmaktadır. İklim değişikliklerinin getirdiği olumsuzluklar çevre ve insan sağlığını tehdit ederek dünyayı yaşanılabilir bir yer olmaktan giderek uzaklaştırmaktadır. Sağlık kurumlarının temel görevi hastalıkların tedavisinden ziyade, hastalıklara yol açan nedenlerin ortadan kaldırılmasında rol almaktadır. Bu nedenle de, insan sağllğını tehdit eden çevre sorunlarının önlenmesinde önemli bir role sahiptir. Son yıllarda sağlık hizmetlerinin sunumunda, kıt olan kaynakların israf edilmediği, çevreye duyarlı uygulamaların ön plana çıkartıldı̆̆ ve insanın sürdürülebilirliğinin teşvik edildiği "Yeşil Hastane” anlayışı önem kazanmıştır. Bu çalışmanın amacl, yeşil hastanelerde uygulanan "yeşil yaklaşımlar”la, muhasebe sistemi içerisinde çevre maliyetlerinin ve maliyet hesaplarının sınıflandırılmasının nasıl oluşturulacă̆ının tespit edilmesidir.
\end{abstract}

Anahtar Kelimeler: Yeşil hastane, Sürdürülebilirlik, Çevre Muhasebesi.

JEL Sınıflandırması: I10,M40, M41,Q56.

\section{Environmental Costs in Green Hospitals and Classification of Cost Accounts}

\section{ABSTRACT}

Rapid population growth in the world, consumer trends and toxic wastes associated with nature cause pollution and greenhouse gases to spread rapidly around the area. The adverse impacts of climate change threaten the environment and human health, thereby increasingly moving the world away from being a liveable place. The main purpose of health institutions is to play a role in eliminating the causes of diseases rather than the treatment of diseases. Therefore, they play an important role in the prevention of environmental problems that threaten human health. In recent years, in the provision of health services, the understanding of "Green Hospitals" has gained importance, where scarce resources are not wasted, environmentally sensitive practices are highlighted and human sustainability is promoted. The aim of this study is to determine how to classify environmental costs and cost calculations within the accounting system with green approaches applied in green hospitals.

Keywords: Green hospital, Sustainability, Environmental accounting.

Jel Classification: I10,M40, M41,Q56.

Makale Gönderim Tarihi: 15.10.2018

Makale Kabul Tarihi: 15.12.2018

Makale Türü: Kuramsal makale

\footnotetext{
* Bu makale, Anadolu Üniversitesi Sosyal Bilimler Enstitüsü’nde, Doç. Dr. Vedat EKERGİL danışmanlığında, Ali Bertan SAVAŞ tarafından hazırlanan "Hastanelerin Yeşil Hastane Olma Süreci, Muhasebenin Rolü ve Bir Uygulama" başlıklı, yüksek lisans tezinden üretilmiştir.

** Prof. Dr., Anadolu Üniversitesi, Açıöğretim Fakültesi, vekergil@ anadolu.edu.tr, ORCID ID: 0000-00026790-8529.

*** Başkent Üniversitesi, Sosyal Bilimler Enstitüsü, bertan.006@gmail.com, ORCID ID: 0000-0002-1176-6867.
} 


\section{GíRiş}

Ortak yaşama alanımızdaki çevre kaynakları, hızlı nüfus artışına bağlı olarak hızla artan tüketim, zehirli atıklar, çevre kirliliği ve çevreye yayılan sera gazları ile kendi ellerimizle yok ettiğimiz ormanlar, olumsuz iklim değişikliklerini beraberinde getirmektedir. $\mathrm{Bu}$ olumsuzlukların devam etmesi, sınırlı olan çevre kaynaklarının yakın bir gelecekte tükenmesi ile karşı karşıya kalabileceğimizi ortaya koymaktadır.

Çevrenin sürdürülebilirliği ve çevre kaynaklarının gelecek kuşaklara miras bırakılabilmesi amacıyla, ülkeler birlikte hareket etmek üzere bir takım düzenlemelere gitmeye başlamışlardır. İlk olarak 1987 yılında, ozon tabakası ve iklim değişikliklerini olumsuz yönde etkileyen zararlı gazların emisyonunun kontrol edilebilmesi amacıyla "Ozon Tabakasını İncelten Maddelere Dair Montreal Protokolü” yürürlüğe girmiş, 1992 yılında ise New York'da "Birleşmiş Milletler İklim Değişikliği Çerçeve Sözleşmesi" uygulamaya konulmuştur. Birleşmiş Milletler'in 1997 yılında Kyoto'da düzenlenen çevre toplantısında, küresel iklim değişikliğiyle mücadele etmek amacıyla kabul edilen "Kyoto Protokolü" 2005 yılında yürüllüğe girmiştir. Sera gazı emisyonlarının azaltılması hedefiyle, 2015 yılı sonunda Paris'te uzlaşıya varılan ve 2016 yılının 46. Dünya Günü’nde Birleşmiş Milletler'in New York'taki merkezinde, aralarında Türkiye'nin de bulunduğu 175 ülke tarafindan imzalanan "Paris Anlaşması" iklim konusunda imzalanmış en kapsamlı anlaşmadır (http://www.radikal.com.tr, 2018 ; https://www.bbc.com, 2018).

Yaşadığımız çevre insan yaşamının devam etmesi için kaynakların sunulduğu bir ortam olmakla birlikte, işletmeler için de ekonomik bir kaynak yaratmakta ve üretim çevreden elde edilen bu kaynaklarla gerçekleştirilmektedir. Bu nedenle; "bugünün gereksinimlerini, gelecek kuşakların gereksinimlerini karşılama yeteneğinden ödün vermeden karşılama" olarak ilk kez 1987 yllında "Brundtland Raporu"nun 27. maddesinde (http://www.un-documents.net, 2018) tanımlanan "sürdürülebilir kalkınma" kavramı önem kazanmış ve son yıllarda özellikle gelişmiş ülkeler, mevcut kaynakların etkin kullanılması, var olan kaynaklar üzerindeki olumsuz etkilerin önlenmesi ve çevreye verilen zararın en aza indirilmesi amacıyla yeni yaklaşım ve projeler geliştirmeye başlamıştır. Bu çevreci hedefler doğrultusunda geliştirilen yeni yaklaşım ve projelerle birlikte, "Yeşil bina", "Yeşil hastane", "Sürdürülebilirlik" ve "Çevre muhasebesi" gibi kavramlarla karşılaşılmaya başlanmıştır. Yaşanan bu gelişmelere paralel olarak mevcut uygulamalarda hangi değişikliklerin yapılması gerektiği irdelenmeye çalışılmıştır.

$\mathrm{Bu}$ çalışmanın amacı, yeşil hastanelerde uygulanan "yeşil yaklaşımlar"ın, geleneksel muhasebe sistemi içerisinde hangi hesap sınıflarında muhasebeleştirilmesi gerektiği konusundaki bilinmezliklere katkı sunmaktır. Sağlık Bakanlı̆̆ özellikle 2012 yllından itibaren "sağlikta enerji verimliliği" projesi ile sağlık sektöründe çevrenin önemini ön plana çıkarmaya yönelik adımlar atmaya çalışmasına rağmen, bu çalışmaların kamu hastanesinde daha başlatılmadığı tespit edilmiştir. Bu kapsamda yapılan çalışmanın ne kadar özgün ve bir gereklilik olduğunu kanıtlamaktadır.

Çalışmanın yöntemi olarak "görüş̧e ve anket" yoluyla veri toplaması gerçekleştirilmiştir. Eskişehir il sınırları içinde 4 kamu, 1 üniversite ve 3 özel hastane ile görüşme yoluyla ve ulusal düzeyde internet yoluyla ulaşılan 23 hastanenin anket sorularına verdiği yanıtlarla sağlık kurumlarının çevre sorunları, maliyetleri ve ihtiyaç duydukları 
maliyet muhasebesi sistemi hakkına bilgi toplanmıştır. Bu verilerden yararlanılarak, sağlık kurumlarının yeşil hastane boyutunda ihtiyaç duyabilecekleri maliyet hesapları sınıflandırılmaya çalışılmıştır.

\section{YEŞİL BİNA}

Yeni binaların yapımı aşamasında, Özdemir'e göre (Özdemir, 2015:34) sürdürülebilir bir yerleşim yerinin seçimi, inşaat, malzeme kullanımı, işletme ve bakım yöntemleri yoluyla, insan sağlığı ve çevre üzerinde yaratılacak olumsuz etkilerin en alt düzeye indirilmesini sağlayan, çevre dostu-yeşil bina olarak ifade ettiği bina projelerine önem verilmiştir. Yeşil bina olarak adlandırılan bu binaların sürdürülebilirlik seviyeleri, 1990'lı yılların sonunda "Amerikan Yeşil Binalar Konseyi (USGBC - U. S. Green Building Council)" tarafından çıkarılan "LEED Yeşil Bina Sertifikası" ile derecelendirilmeye başlanmıştır. Bu sertifika gelişmelere bağlı olarak zaman zaman güncellenerek, "okullar", "otel ve konaklama tesisleri”, "veri merkezleri”, "perakende binaları" ve "hastaneler" gibi bina tiplerine uyarlanmıştır.

\section{3- YEŞİL HASTANE}

Kirk (Kirk, 1998:39) sağlık sektörünü, dünyanın en büyük endüstrilerinden biri olarak görmekte ve insanların varlığını sürdürebilmesi amacıyla hiçbir harcamadan kaçınmadan hizmet üretimi yapan bu sektörde de kâr amacı güdülmesi nedeniyle, hastanelerin doğal çevreye zarar verdiklerini belirtmektedir. Ayrıca, son yıllarda hastanelerin, çevreye verdikleri olumsuz etkileri azaltmak amacıyla çevre yönetim ve koruma sistemlerini kullanarak kârları ile birlikte hasta memnuniyetini de arttırdıkları ve rekabetin yoğun olduğu bu sektörde maliyetlerini azaltan hastanelerin rekabette öne geçmeyi amaçladıkları görülmektedir.

Maliyetlerin kontrol edilerek, tüketicilerin artan beklentilerinin karşılanması ve verimli kaynak kullanımı gerekliliğinin, sağlı sektöründe yeşil hastane kavramını gündeme getirdiği belirtilmekte ve yeşil hastane kavramı; kaynak kullanımında alternatifler üretebilen, enerji, su ve malzemenin daha etkin ve verimli kullanımının teşvik edildiği, her türlü israfın önüne geçilebilen, çevreye duyarlı ve çevre dostu bina tasarımları olan ve hizmet sunumu sürecinde de çevre dostu olabilen hastaneler olarak ifade edilmektedir (Terekli vd., 2013:37).

Dünya standartlarında hizmet sunmayı amaçlayan sağlık kurumları, gerek kamu gerek uluslararası kuruluşlar gerekse hastalar tarafından, çevreye duyarlı bir sağlık hizmeti vermeye zorlanmaktadır. Sağlık sektöründe hastalara sunulan hizmet kalitesi ve fiyat politikası ile cazip hale getirilen sağlık hizmeti, küreselleşen dünya ekonomisi içerisinde ülke sınırlarını ortadan kaldırmakta ve sağlık turizmi kavramını ortaya çıkarmaktadır. Sağlık kurumları arasında yaşanan yoğun rekabet, bu işletmelerin fiyatlarını sınırlı bir bant üzerinde belirlemelerine neden olmakta, ancak hastalar üzerinde sağladıkları güven sayesinde de kârlarını artırabilmektedirler.

Türkiye İstatistik Kurumu'nun (TÜİK) 2016 verilerine bakıldığında; Türkiye'deki sağlık kurumu sayısının 32.980, yataklı sağlık kurumu sayısının 1.510, toplam yatak sayısının 217.771, 1000 kişi başına düşen yatak sayısının ise 2,73 olduğu görülmektedir. Sağlık alanındaki bu potansiyelin daha verimli ve etkin kullanımını sağlamak amacıyla dünyada sayıları hızla artmakta olan yeşil hastane uygulamalarına Sağlık Bakanlığı tarafından Türkiye'de de hız verilerek, kamu ve özel hastanelerin yeşil hastaneye dönüşmesinde önemli 
bir adım olan "Sağlıkta Enerji Verimliliği (SEVER) Projesi" yürürlüğe konulmuştur. 2012 yılında yayınlanan bir genelge ile Sağlık Bakanlığı 200 yatak ve üzeri kapasitedeki tüm hastanelerde uluslararası yeşil bina sertifika sistemi olan LEED'i zorunlu hale getirmesiyle birlikte Türkiye'de "Yeşil Hastane" dönemi başlatılmıştır (https://www.saglik.gov.tr, 2018).

$\mathrm{Bu}$ projede yeşil hastane kavramının "küresel iklim değişikliğine bağlı olarak kendi elektriğini üretecek ve fosil yakıt kullanmayacak uluslararası yeşil bina sertifikası sistemi olan LEED belgesi alınması" şeklinde tanımlanmaktadır. Ancak yeşil hastanelerin kendi enerjisini üreten bir sağlık kurumu olmasının çok daha ötesinde, insan sağlığını tehdit eden çevresel sorunların çözümüne katkı sağlaması ve bu sorunlarla savaşması gerekmektedir. Böylelikle yeşil hastaneler, insanları sağlığına kavuştururken çevreyi kirletmeyecek, kıt kaynakları israf etmeyecek ve sağlıklı insanları sağlığından etmemiş olacaktır.

Dünya Sağlık Örgütü'ne göre (World Health Organization and Health Care Without Harm, 2009:3) yeşil hastanelerde olması gereken unsurlar yedi başlık altında sinıflandırılmaktadır:

1. Enerji verimliliği (hastane enerji tüketimi ve maliyetlerinin verimlilik ve koruma önlemleri ile azaltılması),

2. Yeşil bina tasarımı (bölgenin iklim koşullarına uyan ya da iklim koşullarına uygun hale getirilecek hastane binasının inşa edilmesi), tüketilmesi),

3. Alternatif enerji üretimi (temiz, yenilenebilir enerji üretilmesi ve/veya

4. Ulaşım (hastane araç filolarında alternatif yakıtların kullanması, çalışanların ve hastaların naklinde taşıma ihtiyacının en aza indirilmesi, yürüyüş ve bisiklet kullanımının teşvik edilmesi),

5. Gıda (çalışan ve hastalar için, bölgeye özgü organik gıdalarının sağlanması),

6. Atık (atıkların azaltılmasına yönelik; atıkların organik hale getirilerek yeniden kullanımının sağlanması ve alternatifler üreterek geri dönüşümünün sağlanması),

$\mathrm{Su}$ (su tasarrufu için güvenli alternatiflerin mevcut olması durumunda, şişelenmiş su kullanımından kaçınılması).

\section{DÜNYA'DAKİ YEŞİL HASTANE UYGULAMA ÖRNEKLERİ}

Dünyada yeni inşa edilen ya da mevcut binalarını yenileyerek, sağlık hizmeti verirken "çevre dostu" uygulamalara da önem veren ve "yeşil hastane" olarak adlandırılan birçok sağlık kurumu bulunmakta ve sayıları hızla artmaktadır. Dünya çapında "En İyi 30 Çevre Dostu Hastane"nin belirlenmesi amacıyla hazırlanan rapora göre, en iyi çevre dostu hastanelerin sıralaması yapılmış ve ilk sıralarda yer alan hastanelerin uygulama örneklerine aşağıda yer verilmiştir (Stevens, 2014:1-8).

Raporun ilk sırasında, Amerika Birleşik Devletlerinde ilk LEED sertifikalı çocuk hastanesi kampüslerinden biri olan ve 2009 yllında açılan "Pittsburg Çocuk Hastanesi 
(Children's Hospital of Pittsburgh)" bulunmaktadır. Hastanenin çevre açısından sürdürülebilir girişimleri arasında; damla sulama yapılan su verimli peyzaj sistemi, geri dönüştürülmüş içerikli inşaat malzemelerinin kullanımı ile yapıştırıcı-boya-halı vb. malzemelerde en düşük çevre ve insan sağlığına zarar veren kimyasal (VOC) malzeme kullanımı, hastane iç ortam hava kalitesini arttıran filtreleme sistemi, su kullanımını azaltan armatürler, gün ışığından maksimum faydalanma ve otomatik gölge sistemleri, mümkün olduğunca geri dönüştürülmüş ve yerel araç gereç kullanımı, toplu taşımaya kolay erişim, çalışan-hasta ve hasta yakınları için "yeşil" eğitim programları, \%9,2 oranında yenilenebilir elektrik üretimi, enerji optimizasyon sistemleri ve 1sıtma-soğutma geri kazanım sistemleri, cıva içeren aydınlatma (floresan lamba) ve ekipmanın (laboratuvar tüpleri gibi) kullanılmaması, tıbbi atıkların en aza indirilmesini sağlayan sistem, kağıt kullanılmayan bilgi yönetim sistemi gibi uygulamalar yer almaktadır (http://www.chp.edu, 2018).

LEED Platinum Sertifikasyonunu gerçekleştiren (2008) dünyanın ilk hastanesi olma özelliğini taşıyan "Dell-Teksas Çocuk Tıp Merkezi (Dell Children's Medical Center of Central Texas)" sıralamada ikinci olarak yer almaktadır. Bu özelliği ile hastanenin, sürdürülebilir tasarım ve sağlık mimarisi, su tasarrufu, enerji verimliliği, çevreci satın alma uygulamaları ve kaynakların etkin kullanımı, iç ortam hava kalitesi gibi beş alanda çevre standartlarını aştığı görülmektedir (https://www.dellchildrens.net, 2018).

Amerika Birleşik Devletleri'nde LEED Gold sertifikası alan (2006) ilk hastane olan "Newberg Tıp Merkezi (Providence Newberg Medical Center)" ise raporlamanın üçüncü sırasında yer aldığ 1 ve hastanede; enerji ihtiyacının tamamının yenilenebilir kaynaklardan elde edilmesi, bina konumu, ısıtma ve soğutma verimliliği için gün 1şı̆̆ından en üst düzeyde yararlanılması, binanın bazı bölümlerinde bulunan üstü açık alanlarla arttırılan doğal aydınlatma, 1sıtma-havalandırma ve soğutma (HVAC) sistemlerinin sensörlerle kontrol edilerek dışarıdan sağlanan hava ile iç ortam hava kalitesinin arttırılması gibi çevreci özellikler olduğu görülmektedir (https://oregon.providence.org, 2018).

"En İyi 30 Çevre Dostu Hastane"nin belirlenmesi amacıyla hazırlanan raporda genellikle A.B.D. hastanelerinin olduğu görülmektedir. Diğer ülkelere ilişkin hastane örneklerine bakıldığında ise 10. sırada Kanada'da bulunan ve çevreci uygulamaların yanı sıra LEED Gold sertifikalı diğer tesislere göre \%40 oranında enerji tasarrufu sağlayan "St. Mary's Hospital", 14. sırada Singapur'da bulunan ve enerji tasarrufu, yüksek verimli su sistemleri, sabit sıcaklığın korunmasına yardımcı çevreci bir çatıya sahip, cephe konumlandırmaları ile hasta odalarında serin bir ortam yaratılan "Mount Elizabeth Novena Hospital", 18. sirada İngiltere'de bulunan ve 2007 yılında uygulamaya koydukları enerji verimliliği programı ile karbondioksit emisyonlarını \%28 oranında azaltması nedeniyle, 2012 yılında dünya çapında yeşil enerji alanında mükemmellik işareti olarak kabul edilen "Ashden Ödülü"nü alan "University Hospital of South Manchester: Wythenshawe Hospital" gibi hastaneler yer almaktadır.

\section{TÜRKIYE'DEKİ YEŞIL HASTANE UYGULAMA ÖRNEKLERİ}

Türkiye'de yeşil hastane uygulamalarına son yıllarda önem verilmeye başlandığından araştırıldığında sadece birkaç örnekle karşılaşılmakta ve İstanbul "Florence Nightingale Hastanesi"nin (2013) TUV Hessen Green Building sertifikası ile ülkemizin ilk "Yeşil Hastane Binası" unvanını alan hastanesidir. Hastanedeki ameliyathanelerde, ameliyat masasına doğru 
bir hava akışı sağlanarak hava akımı içerisindeki mevcut partikül ve mikroorganizmaları ortamdan hemen uzaklaştıran yüksek dereceli temizliğin sağlandığı laminar hava akımı donatımı bulunmakta ve görsel-işitsel konferans salonu ile uluslararası noktalara bağlanarak interaktif tıp eğitimi ve bilimsel aktivitelere imkân sağlanmaktadır. Ayrıca ortopedik görüntülemede kullanılan EOS cihazı ile çok düşük Xray ışınları kullanılarak radyasyon dozu en aza indirgenmektedir (https://www.florence.com.tr, 2018; http://a-tec.com.tr, 2018).

"Vehbi Koç Vakfı Amerikan Hastanesi”nin çalışanlarının yanı sıra hasta ve hasta yakınlarına da sağlıklı bir iç ortam hava kalitesi sunmak, sera gazı emisyonu ve karbon ayak izini olabildiğince azaltmak ve hastane anlayışına ekolojik çözüm arayışları yaratmak amaciyla, LEED sertifikasının en üst seviyesi olan LEED EBOM (mevcut hastane) sertifikasına platin seviyesinde aday olmuştur (http://smartecodesign.com, 2018).

Bir başka örnek ise 2018 yılı başında açılan "Memorial Bahçelievler Hastanesi" dünyanın ilk LEED Platinum sertifikalı tam teşekküllü hastanedir. Hastane tasarımının çalışanlar ile hasta ve yakınlarının konforu için, poliklinikler ile hasta bekleme noktalarından çalışan ve hasta odalarına, renk seçiminden eşya formlarına, 1şıklandırmadan seçilen aksesuarlara, enerji verimliliğinden atık yönetimine, sürdürülebilir alan planlamasından iç ortam hava kalitesine kadar her detayın iyileşmenin bir parçası olarak planlanarak inşa edilmiştir (https://www.memorial.com.tr, 2018).

\section{YEŞILL HASTANELER VE SÜRDÜRÜLEBILLIRLIKK}

Gelecek nesillere yaşanabilir bir çevrenin miras bırakılabilmesi amacıyla ortaya çıkan sürdürülebilirlik kavramı, "Brundtland Raporu" olarak bilinen, "Birleşmiş Milletler Çevre ve Kalkınma Komisyonu Raporu: Ortak Geleceğimiz (Report of the World Commission on Environment and Development: Our Common Future)" raporunun, "3. Sürdürülebilir Kalkınma" başlığı altında bulunan 27. maddesinde "bugünün gereksinimlerini, gelecek kuşakların gereksinimlerini karşılama yeteneğinden ödün vermeden karşılama" olarak tanımlanmaktadır.

Sezer'e göre (Sezer, 2007:762) sürdürülebilir kalkınma, insan-doğa ve toplum arasındaki ilişkilere farklı bir bakış açısıyla yaklaşan gelişme stratejisidir. Sürdürülebilir kalkınmanın evrensel olarak bütün ülkeler tarafindan benimsenmesi ve yaşama geçirilmesinin önemli, ancak yeterli olmadığı belirtilmektedir. Ayrıca, çevre sorunlarının önlendiği ve çevreyi korumacı bir anlayışın yansıtıldığı sürdürülebilir kalkınmanın, insan, doğa ve toplumsal anlayış temellerinin sorgulanması ve çevre sorunlarının küresel boyutta tartışılarak çözüm önerilerinin ortaya konulması ile mümkün olabileceği vurgulanmaktadır.

Sağlı sektöründe sürdürülebilir kalkınmanın; hastanelerin gerek alt yapıları gerekse iş süreçlerinde, kaynakların sürdürülebilirliği ile kaynakların etkin ve verimli kullanılması, tıbbi ve tıbbi olmayan malzeme israfının önlenmesi, hizmet kalitesi ile hasta güvenliğinin arttırılması, geleneksel arşivleme işlemlerden vazgeçilmesi ve maliyetlerin azaltılması gibi çevreci uygulamalar ile mümkün olacağı görülmektedir (Terekli vd., 2013:50). 


\section{YEŞİL HASTANELERIN ÖNEMI}

Gökdemir'e göre (Gökdemir, 2008:23) dünyanın 3/4'ünün sularla kaplı olmasına rağmen, 40 ülkede 2 milyardan fazla kişinin su kıtlığından etkilendiği, 1.1 milyar kişinin yeterli seviyede içme suyuna ulaşamadığı ve iyimser bir tahminle 2050 yılında her dört kişiden birinin ise yeterli içme suyuna ulaşamayacağı öngörülmektedir. EPA'ya göre (United States Environmental Protection Agency [EPA], 2012:1) Amerika'da ticari ve kuramsal tesislerde kullanılan su miktarının \%7'sinin hastanelerde kullanılmakta, kullanılan suyun \%7'si mutfak ve bulaşık yıkamada, \%7'si çevre düzenlemede, \%20'si soğutma ve isıtmada, \%35'i iç temizlik ve tuvaletlerde, \%15'i tıbbi malzemelerin durulamasında (ön temizlik, dezenfekte, sterilize vb.), \%9'u çamaşırhanelerde, \%7'si ise diğer alanlarda tüketilmektedir.

Hastanelerde mevsim şartlarına göre yaşam koşullarının sağlanması gerekmektedir. Ancak bu koşullar sağlanırken titreşim ve gürültünün engellenmemesi, sistemlerde gerekli bakım ve yalıtımların yapılmaması, hastanenin iç ortam hava kalitesinin bozulması ile hastanelerde bakım ve enerji maliyetleri de artmaktadır.

7/24 kesintisiz hizmet veren hastanelerin, yılda yaklaşık 836 trilyon BTU'luk (450 gr. suyun sıcaklığını 2 fahrenhayt arttırmak için gerekli olan enerji miktarını gösteren enerji birimi) enerji kullanımıyla enerji tüketimi en fazla olan kurumlardan olduğu ve bir hastanenin, normal bir ticari işletmenin enerji tüketiminin 2,5 katından fazla enerji tüketmektedir (United States Department of Energy Office of Energy Efficiency and Renewable Energy, 2008).

İnsanları sağlı̆̆ına kavuşturabilmek amacıyla verilen sağlık hizmetleri sırasında, bulaşıcı hastalık taşıyan ya da taşıması muhtemel, kan, vücut sıvısı, doku parçaları, örtü, çarşaf, eldiven, şırınga, iğne, bisturi, tüp, kimyasal madde, kanserojen ve radyoaktif materyaller vb. atıklar ortaya çıkmaktadır. TÜİK' in 2012-2016 y1llarını kapsayan "Tıbbi Atık Göstergeleri, 2012-2016" verilerine göre; 2012 yılında 1.449 sağlık kuruluşunda 68.929 ton/yıl olan tıbbi atık miktarının, 2016 yılında 1.527 sağlık kuruluşunda 81.024 ton/yıldır.

$\mathrm{Bu}$ bağlamda hastanelerde yenilikçi çevresel tasarımlarla birlikte, çevre kirliliği, enerji, su, atık bertaraf maliyetleri ile işletme giderlerinin azaltılması, hasta bakım kalitesinin arttırılması ve hastanelerin imajının iyileştirilmesine yönelik olarak;

- Çevre üzerindeki etkilerin değerlendirilerek, sonuçların ölçülüp denetlenebildiği,

- Standart ve prosedürlerin oluşturularak uygulanabildiği,

- Farkındalık yaratılarak davranışların değiştirilebildiği,

- Yeni çevreci politikalar oluşturularak sürekli bir iyileştirme arayışına girilebildiği,

- Çevre kirliliği ile maliyetlerin azaltılarak performansın arttırılmasında çalışanların aktif görev üstlenebildiği görülmekte ve "yeşil hastane"lerin önemi ortaya konulmaktadır (Environment Science Center, 2003:6). 


\section{YEŞILIL HASTANELERDE "ÇEVRE MUHASEBESİ"}

Çevre muhasebesi; gerek çevre kirliliği gerekse çevre sorunlarının önlenemez yükselişinin kaynağı olduğu düşünülen işletmelerin, üzerine düşen görevleri yerine getirmesi gerektiği konusunda fikir birliğine varılması üzerine gündeme gelmiş (Otlu ve Kaya, 2010:44). Uluslararas1 Standartlar Örgütü'nün 1973 yllında başlayıp 1992 yilında yapılandırdığı "ISO 14000 Çevre Yönetim Standartları" ile mevcut muhasebe sisteminde yeni bir yaklaşım olarak tanınmaya başlamıştır (Çalış, 2013:180).

Sürdürülebilirliğinin sağlanması ve çevreci uygulamalara karşı gösterilen hassasiyet ile "çevre muhasebesi" yaklaşımının ön plana çıktığı, ancak konuya ilişkin kaynaklar incelendiğinde, çevre muhasebesi tanımının farklı biçimlerde yapıldığı ve yine çevre muhasebesi yerine eşanlamlı bazı kavramların da (yeşil muhasebe, doğa muhasebesi, ekolojik muhasebe vb.) kullanılmış olduğu görülmektedir.

Çevre muhasebesinin çoğu kaynakta borçlanma maliyetleri ya da atık yönetimi gibi maliyetler üzerinde durularak, çevreye özgü maliyetlerin belirlenmesi ve raporlanması temelinde ele alınmaktadır. Boyd (Boyd, 1994:3-4) göre, yeşil hastanelerde çevre muhasebesinin; muhasebeden ziyade, çevresel faydanın sağlanması amacıyla gerekli maliyetlerin tespit edilmesine yönelik, hastanenin mali bilgilerinin daha düzenli biçimde kayıt altına alındığı, hastanenin vereceği sağlık hizmeti süreçlerindeki değişikliklerin (ürün/üretim), çevre üzerindeki etkilerinin de ortaya konularak, herhangi bir maliyet ve kârın da muhasebeleştirildiği bir sistem olarak tanımlanabilir.

\section{YEŞIL HASTANELERDE ÇEVRE MALIYYETLERİ VE MALIYETLERIN SINIFLANDIRILMASI}

Çevre maliyetleri, işletmelerin kendi hedef kitlelerine, mal veya hizmet sunmak amacıyla katlandıkları maliyetlerden biridir (Özbirecikli, 2000:18). Sürdürülebilirliğin sağlanabilmesi amacıyla, sağllk sektöründe yeşil hastanelerde çevreci uygulamalar ön plana çıkmaktadır. Özyaral'a göre (Özyaral, 2013:230); en alt seviyede enerjinin kullanıldı̆̆ı, su tasarrufunun en üst düzeyde sağlandığı, atıkların azaltıldığı, geri dönüşümün desteklendiği, çevreye zarar veren hiçbir ürünün satın alınmadığı, "yeşil" ve "doğa" konusunun savunulduğu, yaşam alanlarında ve ekonomik çerçevede yer alan istenilmeyen etkenlerden arındırıldığı, yerel ürünlerin üretim ve tüketiminin teşvik edildiği çevreci politikalardan oluşmaktadır.

Yeşil hastanelerde çevreci bir sağlık hizmeti sunulması beklenilmektedir. Ancak bu hizmet sunumunda gerekli olan; en az enerji ve suyun kullanılması, geri dönüşümün desteklenmesiyle atıkların azaltılması, çevreye duyarlı ürünlerin kullanılması, gerek yürüme gerek dinlenme gerekse bisiklet kullanımına yönelik yeni çözümlerin üretilmesi, mevcut otopark alanlarının düzenlenmesi (güneş paneli, elektrikli araçlar için şarj sistemi vb.) gibi çevreci uygulamalarda katlanılması gereken zorunlu "çevre maliyetleri”ni ortaya çıkarmaktadır.

Çevre maliyetleri; ortaya çıkış zamanlarına göre, kapsamlarına göre, toplam kalite yaklaşımına göre sınıflandırılabilmektedir. Yeşil hastanelerdeki maliyet sınıflandırması ise şöyledir: 


\section{1) Ortaya cıkıs bicimlerine göre:}

a) Önleme/azaltma maliyetleri (çevre planlama, emisyon ölçümü, geri dönüşüm, çevresel eğitim, Ar-Ge vb. çevresel sorunların önlenebilmesi ya da azaltılması),

b) Kullanma maliyetleri (hava, su toprak, enerji vb. çevresel kaynakların kullanılması),

c) Zarar maliyetleri (hava, su, toprak, gürültü kirliliği maliyetleri ile çevre temizleme ve diğer zarar maliyetleri gibi çevresel zararlar) biçiminde (Ulusan, 2010:79),

\section{2) Birimlerin faaliyetlerine göre:}

a) Faaliyet alanı maliyetleri (kirliliği önleme, küresel çevre koruma ve kaynak geri dönüm maliyetleri),

b) Isslem öncesi (mal veya hizmetin girmesinden önce çevreye duyarlı ürün alımı gibi ortaya çıkan çevre maliyetleri)

c) İslem sonrası maliyetler (mal veya hizmetin yeşil hastaneye girdikten sonra ortaya çıkan, kullanılan ürünlerin toplanması-geri dönüşümü-uygun bir biçimde elden çıkarılması gibi çevresel etkilerin azaltılmasına yönelik maliyetler),

d) Yönetim maliyetleri (yeşil hastane ve diğer kuruluşlar tarafindan çevre korumasına ilişkin yürütülen, çevre yönetim sistemi uygulaması, çevreci reklâm, çevresel etkilerin izlenmesi, çalışanlara verilen çevre eğitim giderleri, çevrenin korunmasi/yeşillendirilmesi gibi yönetim faaliyetlerini oluşturan maliyetler),

e) Ar-ge maliyetleri (çevresel etkinin azaltılması, çevrenin korunmasına katkı sunan ürün geliştirilmesi gibi çevresel korumaya yönelik araştırma geliştirme maliyetleri),

f) Sosyal faaliyet maliyetleri (yeşil hastanelerde sosyal alan kullanımına ayrılan yerlerin yeşillendirilmesi ve doğayı koruma faaliyetleri gibi maliyetler),

g) Cevresel iyileștirme maliyetleri (yeşil hastanelerdeki faaliyetler sonucunda ortaya çıkabilecek olası, doğal çevrenin orijinal hale getirilmesi, çevresel konulardaki mevcut kanun/yönetmeliklere uyulmaması nedeniyle ortaya çıkan cezai yaptırımlar, sigorta ücretleri gibi, çevresel bozulmaların düzeltilmesine yönelik maliyetler) ile

h) Diğer maliyetler (çevresel iyileştirme maliyetleri dışında kalan, tamamlayıcı kategoriler sınıfında sıralanan ve sadece çevre koruma maliyetinin bir kısmının karşılanabildiği diğer maliyetler) olarak (Ministry of The Environment Government of Japan, 2005:14-21).

\section{3- Cevre Koruma Kurumu'na göre:}

a) Geleneksel maliyetler (ekipman, iş gücü, malzeme kullanımı, bina, elektrik ve su gibi hizmet maliyetleri), 
b) Potansiyel gizli maliyetler (ar-ge, izin vb. ön maliyetler, raporlama, düzeltme, eğitim, denetleme, etiketleme vb. düzenleyici maliyetler, geri dönüşüm, eğitim, peyzaj, çevresel projeler vb. gönüllü maliyetler ile kapatma, hizmet dışı bırakma, bakım vb. arka uç maliyetler),

c) Kossullu maliyetler (uyum, düzeltme, mülk, doğal kaynak ve ekonomik kayıp zararları gibi maliyetler),

d) İmaj/ilişki maliyetleridir (yeşil hastanelerin imaji ile hasta-çalışan-toplum kuruluşları ilişkilerinden oluşan maliyetler) (United States Environmental Protection Agency, 1995:9).

$\mathrm{Bu}$ örneklere bakıldığında, çevre maliyetlerinin sınıflandırılmasında farklı bakış açılarından ele alınan çeşitli yaklaşımların olduğu görülse de, çevre maliyeti sınıflandırmalarında hangi yaklaşımın kullanılacağı konusunda, düzenleyici kurumlarca karar verilmesi gerekmektedir.

\section{YEŞIL HASTANELERDE SINIFLANDIRILAN ÇEVRE MALIYETLERINE ILIŞKIN, TEKDÜZEN HESAP PLANININ OLUŞTURULMASI}

Genel bir düzenleme olan tekdüzen muhasebe sistemi; Haftacı ve Soylu'ya göre (Haftacı ve Soylu, 2008:106) muhasebenin temel kavram ve politikalarını, mali tabloların ilkeleri ile sunulmasını, hesap planının çerçevesi ve işleyişini açıklayan bir muhasebe sistemi olarak tanımlanmaktadır. Tekdüzen muhasebe sisteminde, çevre muhasebesi bağlamında hiçbir ifadeye yer verilmese de, serbest bırakılan 8 ve 0 numaralı hesaplarla, boş bırakılan hesap grupları ve ana hesapların, yeşil hastanelerin hesap planı kullanmalarında bir esneklik sağladığı ve bu esnekliklerin gereksinimler doğrultusunda çevresel uygulamalara tahsis edilebileceği görülmektedir. Tekdüzen hesap planının "24 Mali Duran Varlıklar" ile "25 Maddi Duran Varlıklar" gruplarında esneklik bulunmamasının, yeni hesap açma olanağını ortadan kaldırdı̆̆ 1 ve "çevresel maddi duran varlıkların", "diğer duran varlıklar" ya da alt hesaplarda izlenebileceği, buna rağmen çevresel uygulamaların izlenmesi yönünden tekdüzen hesap planının bir sorun yaratmayacağı vurgulanmaktadır. Tekdüzen hesap planındaki esneklikten yararlanılarak, hesap sinıfi, hesap grubu, ana hesap ve alt hesap düzeylerinde yeni hesapların açılarak, çevresel uygulamaların istenilen boyutlarda izlenmesinin mümkün olacağı, ayrıca serbest bırakılan 8 ve 0 numaralı hesap sınıflarının da kullanılabileceği belirtilmektedir.

Çevre maliyetlerinin detaylı olarak sınıflandırılması ve tekdüzen hesap planının oluşturulmasında, Özbirecikli ve Melek (Özbirecikli ve Melek, 2002:85) ile Jasch (Jasch, 2003:110) tarafından yapılan sınıflandırmaların ön plana çıktı̆̆ı görülmekte ve yapmış oldukları sinıflandırmalara Tablo 1'de yer verilmektedir. 
Tablo 1. Çevre Maliyetlerinin Detaylı Sınıflandırılması

\begin{tabular}{|c|c|}
\hline Özbirecikli ve Melek'in sınıflandırması & Jasch'ın sınıflandırması \\
\hline $\begin{array}{l}\text { Azaltma (kaçınma) maliyetleri } \\
\text { Çevre planlaması } \\
\text { Süreç kontrol } \\
\text { Emisyon ölçüm cihazları } \\
\text { Çevreye zararsız mamul tasarım geliştirme } \\
\text { Geri dönüşüm tasarımları } \\
\text { Çevreye zararsı ambalaj geliştirme } \\
\text { Çevre geliştirme } \\
\text { Çevresel eğitim } \\
\text { Biyolog, kimyager hizmetleri } \\
\text { Çevre mühendislik hizmetleri } \\
\text { Çevre raporları } \\
\text { Çevre etiketleri } \\
\text { Çevre güvenirlik } \\
\text { Çevre yönetim sistemi } \\
\text { Çevre denetimi } \\
\text { Kullanma maliyetleri } \\
\text { Hava maliyeti } \\
\text { Su maliyeti } \\
\text { Toprak maliyeti } \\
\text { Gürültü maliyeti } \\
\text { Görüntü maliyeti } \\
\text { Doğal gaz maliyeti } \\
\text { Petrol maliyeti } \\
\text { Kömür maliyeti } \\
\text { Enerji maliyeti } \\
\text { Zarar (hasar) maliyetleri } \\
\text { Hava kirliliği } \\
\text { Su kirliliği } \\
\text { Görüntü kirliliği } \\
\text { Cezalar ve tazminatlar } \\
\text { Çevre temizleme } \\
\text { Şikâyet araştırmaları } \\
\text { Kefalet ve garanti giderleri } \\
\text { Satıs azalmaları } \\
\text { Diğer zarar maliyetleri } \\
\end{array}$ & $\begin{array}{l}\text { A. Hava ve iklim, } \\
\text { B. Atık su, } \\
\text { C. Su, } \\
\text { D. Toprak ve yeraltı suları, } \\
\text { E. Gürültü ve titreşim, } \\
\text { F. Biyo-çeşitlilik ve peyzaj, } \\
\text { G. Radyasyon (ışıma), } \\
\text { H. Diğer } \\
\text { 1. Atık ve emisyon işlemleri } \\
\text { 1.1. İlgili ekipman için amortisman } \\
\text { 1.2. Bakım, işletim malzemeleri ve hizmetler } \\
\text { 1.3. İlgili personel maliyetleri } \\
\text { 1.4. Ücretler, vergiler, harçlar } \\
\text { 1.5. Para cezaları ve cezalar } \\
\text { 1.6. Çevresel yükümlülükler için sigorta } \\
\text { 1.7. Temizleme masrafları, iyileştirme hükümleri } \\
\text { 2. Önleme ve çevre yönetimi } \\
\text { 2.1. Çevre yönetimi için dış hizmetler } \\
\text { 2.2. Genel çevre yönetimi faaliyetleri için personel } \\
\text { 2.3. Araştırma ve Geliştirme } \\
\text { 2.4. Temiz teknolojiler için ekstra harcama } \\
\text { 2.5. Diğer çevre yönetimi maliyetleri } \\
\text { 3.Ürün dışı çıtıların malzeme satın alma değeri } \\
\text { 3.1. İşlenmemiş içerikler } \\
\text { 3.2. Paketleme } \\
\text { 3.3. Yardımcı malzemeler } \\
\text { 3.4. İşletim malzemeleri } \\
\text { 3.5. Enerji } \\
\text { 3.6. Su } \\
\text { 4.Ürün dışı çıttıları işleme maliyetleri } \\
\text { al }\end{array}$ \\
\hline
\end{tabular}


Yine 26.12.1992 tarih ve 21447 Mükerrer sayılı Resmî Gazete'de yayımlanarak yürürlüğe giren "Muhasebe Sistemi Uygulama Genel Tebliği Sira No:1" ile işletmelerin maliyet hesaplarına ilişkin olarak parasal limitlere göre ilgili y1l içerisinde hesaplanacak aktif toplamı rakamı veya net satışlar rakamını aşan üretim ve hizmet işletmeleri için 7/A seçeneğinin kullanımı zorunlu hale getirilmiştir.

İlgili tebliğ gereğince "Maliyet Hesapları"nın 7/A seçeneği hesap planına Tablo 2'de yer verilmektedir (http://www.gib.gov.tr, 2018).

Tablo 2. Maliyet Hesaplarının 7/A Seçeneği Hesap Planı

\section{MALIYYT MUHASEBESİ BAĞLANTI HESAPLARI}

700. MALIYET MUHASEBESI BAĞLANTI HESABI

701. MALIYET MUHASEBESI YANSITMA HESABI

71 DIREKT ILKMADDE VE MALZEME GIDERLERI

710. DİREKT İLKMADDE VE MALZEME GIDERLERI

711. DİREKT İLKMADDE VE MALZEME YANSITMA HESABI

712. DIREKT İLKMADDE VE MALZEME FIYAT FARKI

713. DIREKT İLKMADDE VE MALZEME MIKTAR FARKI

72 DİREKT İŞÇILIIK GIDERLERİ

720. DİREKT İŞÇILIK GIDERLERİ

721. DİREKT İŞCILIK GIDERLERİ YANSITMA HESABI

722. DIREKT İŞÇILİK ÜCRET FARKLARI

723. DİREKT İ̧ÇILIKK SÜRE (ZAMAN) FARKLARI

73 GENEL ÜRETIM GIDERLERI

730. GENEL ÜRETIM GIDERLERİ

731. GENEL ÜRETIM GIDERLERI YANSITMA HESABI

732. GENEL ÜRETIM GIDERLERİ BÜTÇE FARKLARI

733. GENEL ÜRETIM GIDERLERI VERIMLILIKK FARKLARI

734. GENEL ÜRETIM GIDERLERI KAPASITTE FARKLARI

74 HIZMET ÜRETIM MALIYETI

740. HIZMET ÜRETIM MALIYETİ

741. HIZMET ÜRETIM MALIYETI YANSITMA HESABI

742. HIZMET ÜRETIM MALIYETI FARK HESAPLARI

75 ARAŞTIRMA VE GELIŞTIRME GIDERLERI

750. ARAŞTIRMA VE GELIŞTIRME GIDERLERİ

751. ARAŞTIRMA VE GELIŞTTIRME GIDERLERİ YANSITMA HESABI

752. ARAŞTIRMA VE GELIŞTIRME GIDER FARKLARI

76 PAZARLAMA SATIŞ YE DAĞITIM GIDERLERİ

760. PAZARLAMA SATIŞ VE DAĞITIM GIDERLERİ 


\author{
761. PAZARLAMA SATIŞ VE DAĞITIM GIDERLERİ YANSITMA HESABI \\ 762. PAZARLAMA SATIŞ VE DAĞITIM GIDERLERİ FARK HESABI \\ 77 GENEL YÖNETIM GIDERLERI \\ 770. GENEL YÖNETIM GIDERLERİ \\ 771. GENEL YÖNETIM GIDERLERİ YANSITMA HESABI \\ 772. GENEL YÖNETIM GIDER FARKLARI HESABI \\ 78 FINANSMAN GIDERLERI \\ 780. FINANSMAN GIDERLERİ \\ 781. FINAANSMAN GIDERLERİ YANSITMA HESABI \\ 782. FINANSMAN GIDERLERI FARK HESABI
}

Yeşil hastanelerde çevre maliyetlerinin hangi hesaplarda izlenebileceğine ilişkin olarak kaynaklarda hiçbir örneğe rastlanılamaması, bu konudaki belirsizlikleri de beraberinde getirmektedir. Tablo 1'de yer verilen çevre maliyetleri (Özbirecikli ve Melek, 2002:85), Tablo 2'de yer alan ana hesap gruplarından "740 Hizmet Üretim Maliyeti” hesabının altında Tablo 3'te verilmekte olan yardımcı hesaplar kullanılabilir.

Tablo 3. Çevre Maliyetleri Yardımcı Hesapları Örneği

\begin{tabular}{|c|c|}
\hline \multicolumn{2}{|l|}{ 99. ÇEVRE MALIYYETLERİ } \\
\hline 990.Azaltma (Kaçınma) Maliyetleri & 991. Kullanma Maliyetleri \\
\hline 990.001. Çevre Planlaması & 991.001. Hava Maliyeti \\
\hline 990.002. Süreç Kontrol & 991.002. Su Maliyeti \\
\hline 990.003. Emisyon Ölçüm Cihazları & 991.003. Toprak Maliyeti \\
\hline 990.004. Çevreye Zararsız Mamul Tasarım & 991.004. Gürültü Maliyeti \\
\hline Geliştirme & 991.005. Görüntü Maliyeti \\
\hline 990.005. Geri Dönüşüm Tasarımları & 991.006. Doğalgaz Maliyeti \\
\hline 990.006. Çevreye Zararsız Ambalaj Geliştirme & 991.007. Petrol Maliyeti \\
\hline 990.007. Çevre Geliştirme & 991.008. Kömür Maliyeti \\
\hline 990.008. Çevresel Eğitim & 991.009. Enerji Maliyeti \\
\hline 990.009. Biyolog, Kimyager Hizmetleri & 991.010. Diğer Kullanma Maliyetleri \\
\hline \multicolumn{2}{|l|}{ 990.010. Çevre Mühendislik Hizmetleri } \\
\hline 990.011. Çevre Raporları & 992. Zarar (Hasar) Maliyetleri \\
\hline 990.012. Çevre Etiketleri & 992.001. Hava Kirliliği \\
\hline 990.013. Çevre Güvenirlik & 992.002. Su Kirliliği \\
\hline 990.014. Çevre Yönetim Sistemi & 992.003. Görüntü Kirliliği \\
\hline 990.015. Çevre Denetimi & 992.004. Cezalar ve Tazminatlar \\
\hline \multirow[t]{5}{*}{ 990.016. Diğer Azaltma (Kaçınma) Maliyetleri } & 992.005. Çevre Temizleme \\
\hline & 992.006. Şikâyet Araştırmaları \\
\hline & 992.007. Kefalet ve Garanti Giderleri \\
\hline & 992.008. Satış Azalmaları \\
\hline & 992.009. Diğer Zarar Maliyetleri \\
\hline
\end{tabular}


İşletmeler, tercih etmesi durumunda bu çevre maliyetlerini; Tablo 3'te örneği verilen yardımcı hesaplar yardımıla, "0" ve " 8 " numaralı "serbest" hesaplarda ayrıntılı olarak istedikleri boyutta ayrıca izleyebileceklerdir. Böylece Tablo 3'te yer alan örnek hesapla, hastanenin maliyet detayları gözden kaçırılmamış olacak ve gerekli raporların hazırlanmasında büyük kolaylık sağlanacaktır. Ayrıca, bu hesaplar altında oluşturulacak yeni hesaplarla, muhasebe ilkeleri ile eş zamanlı maliyet tespit etme yöntemlerine uyularak, dönem sonlarında mali tablolara geçiş yapılmadan ilgili hesaplarla karşılaştırılarak kapatılabilecektir.

\section{SONUÇ VE ÖNERILER}

Son yıllarda dünyada yeşil hastane sayıları hızla artmakta, Türkiye'de yeşil hastane niteliğindeki hastane sayısı ise parmakla gösterilebilecek kadar az sayıda bulunmaktadır. Buna rağmen Sağlık Bakanlı̆̆ı tarafından uygulamaya konulan yatırım projeleri ve kararlarla 200 ve üzeri yatak kapasitesine sahip hastanelerin yeşil hastaneye dönüştürülmeleri ile önümüzdeki kısa dönemde yeşil hastane sayılarında mutlak bir artış olacaktır. Ancak önümüzdeki yıllarda yeşil hastane sayılarının artması, bu hastanelerdeki çevreci uygulamaların geleneksel muhasebe sistemi içerisinde nasıl muhasebeleştirilmesi gerektiği konusundaki bilinmezlikleri de beraberinde getirecek, bu bilinmezliklerin çözümü ise "Çevre Muhasebesi" yaklaşımı ile mümkün olabilecektir.

Çevresel faydanın sağlanması amacıyla, çevre maliyetlerinin belirlenmesine önem verilmeli ve çevresel uygulamalar etkin olarak kullanılmalıdır. Yeşil hastaneye ilişkin çevreci uygulama maliyetlerinin muhasebeleștirilmesi; "7" hesap sınıfının içerisindeki "740 Hizmet Üretim Maliyeti" ana hesabının yardımcı hesapları ile gerçekleştirilecek ayrıca tercih eden işletmeler tarafindan, serbest birakılan " 8 " ve " 0 " numaralı hesap sinıflarında da ayrıntılı olarak izlenebilecektir.

Çevreci uygulamaların muhasebeleştirilmesi amacıyla, ilgili kurum/kuruluşlarca açılması gereken yeni hesap kodları ve hesap adları belirlenmeli, farklı işletme grupları tarafindan kullanılan TMS/TFRS, Büyük ve Orta Boy İşletmeler İçin Finansal Raporlama Standardı (BOBİ FRS) ve Tekdüzen Hesap Planında gerekli güncellemeler yapılarak merkezi bir birlik sağlanmalı ve "ilgili kişiler tarafından nasıl kullanılması gerektiğı" konusunda eğitimler verilmelidir.

Ayrıca, üniversitelerde "Çevre Muhasebesi" derslerine önem verilmeli ve yapılacak yeni araştırmalarda özellikle ilgili konular üzerinde durularak, çevreci uygulamaların nasıl muhasebeleştirilmesi gerektiği konusunda "farkındalık" yaratılmalıdır.

\section{KAYNAKLAR}

Boyd, James (1998), "The Benefits of İmproved Environmental Accounting: An Economic Framework to Identify Priorities", Discussion Paper, 98(49), pp.1-26.

Çalış, Yıldırım Ercan (2013), "Çevresel Maliyetlerin Muhasebeleştirilmesi", Marmara Üniversitesi İ.İ.B. Dergisi, 34(1), ss.175-190.

Environment Science Center (2003), "Greener Hospitals: Improving Environmental Performance", Germany: Bristol-Myers Squibb Company, pp.1-52. 
Gökdemir, Bülent (2008), "Küresel Su Krizine Çözüm Arayışları: Şebeke Suyu Hizmetlerine Özel Sektör Katılımı", İstanbul: Türk Sanayicileri ve İşadamları Derneği, Yayın No: TÜSİAD-T/2008-09/470, ss.1-152.

Haftacı, Vasfi - Soylu, Kamuran (2008), "Çevresel Bilgilerin Muhasebesi ve Raporlanması", Kocaeli Üniversitesi Sosyal Bilimler Enstitüsü Dergisi, 15(1), ss.92-113.

Jasch, Christine (2003), "The Use of Environmental Management Accounting (EMA) Foridentifying Environmental Costs", Journal of Cleaner Production, 11(6), pp.667676.

Otlu, Fikret - Kaya, Gamze Ayça (2010), "Çevre Muhasebesi ile İlgili Muhasebe Meslek Mensupları Üzerine Bir Araştırma", Akademik Yaklaşımlar Dergisi, 1(1), ss.43-56.

Özbirecikli, Mehmet (2000), "Çevre Muhasebesi Kavramı ve Yönetsel Kararlara Katkıları", Muhasebe ve Finansman Dergisi (MUFAD), 7, ss.18-26.

Özbirecikli, Mehmet - Melek, Zeynep (2002), "Çevre Muhasebesi Çevresel Maliyetlerin Maliyet Muhasebesi Sistemine Etkisi", Muhasebe ve Finansman Dergisi (MUFAD), 14, ss.85-90.

Özdemir, M.Tolga (2015), "Hastaneler ve Sağlık Tesisleri İçin LEED Yeşil Bina Sertifikası",Yeşil Bina Dergisi, 33, ss.34-35.

Özyaral, Oğuz (2013), Yeşil Hastane, Haydar Sur ve Tunçay Palteki (Ed.), Hastane Yönetimi, İstanbul: Nobel Tıp Kitabevleri Ltd. Şti., ss.219-235.

Kirk, David (1998), "Attitudes to Environmental Management Held by a Group of Hotel Managers in Edinburgh", International Journal of Hospitality Management, 17(1), pp.3347.

Ministry of The Environment Government of Japan (2005), "Environmental Accounting Guidelines", Tokyo, pp.14-21.

Sezer, Özcan (2007), "Küresel Konferanslar ve Çevre Sorunları: Çevre Kalkınma ve Etik Açısından Eleştirel Bir Değerlendirme", Uluslararası Asya ve Kuzey Afrika Çalışmaları Kongresi (ICANAS 38), ss.761-780.

Stevens, Tom (2014), "30 Most Environmentally Friendly Hospitals in the World", Healthcare Administration Degree Programs, pp.1-8.

Terekli, Gözde - Özkan, Okan - Bayın, Gamze (2013), "Çevre Dostu Hastaneler: Hastaneden Yeşil Hastaneye”, Ankara Sağlık Hizmetleri Dergisi, 12(2), ss.37-54.

Ulusan, Hikmet (2010), "Türkiye Muhasebe - Finansal Raporlama Standartları'nın Çevresel Maliyet ve Borçların Muhasebeleştirilmesi ve Raporlanması Açısından İncelenmesi”, Selçuk Üniversitesi Sosyal Ekonomik Araştırmalar Dergisi, 13(19), ss 75-99. 
United States Department of Energy Office of Energy Efficiency and Renewable Energy (2008),"EnergySmart Hospitals: Creating Energy Efficent, High Performance Hospitals", Building Technologies Program, pp.1-2, https://www1.eere.energy.gov/buildings/

publications/pdfs/energysmarthospitals/esh_factsheet.pdf (05.07.2018).

United States Environmental Protection Agency (1995), "An Introduction to Anvironmental Accounting as a Business Management Tool: Key Concept and Terms", Washington, pp.1-38, https://www.epa.gov/p2/introduction-environmentalaccounting-business-management-tool-key-concepts-and-terms (05.07.2018).

United States Environmental Protection Agency [EPA] (2012), "Saving Water in Hospitals", Washington, pp.1-2, https://www.epa.gov/sites/production/files/201701/documents /ws-commercial-factsheet-hospitals.pdf (05.07.2018).

World Health Organization and Health Care Without Harm (2009), "Healthy Hospitals, Healthy Planet, Healthy People: Addressing Climate Change in Health Care Setting", England, pp.1-28, https://www.who.int/globalchange/publications/healthcare_settings/en/ (13.04.2017).

http://a-tec.com.tr/laminer-hijyenik-hava-akis-unitesi (05.07.2018).

https://www.bbc.com/turkce/haberler/2016/04/160422_paris_iklim_anlasmasi_imza (16.07.2018).

http://www.chp.edu/news/031711-leed-certification (04.07.2018).

https://www.dellchildrens.net/about-us/building-details/about-our-green-building/ (07.2018).

https://www.florence.com.tr/istanbul-florence-nightingale-hastanesi (05.07.2018).

http://www.gib.gov.tr/fileadmin/mevzuatek/eski/muhsisteblekmuh5b.htm (15.08.2018).

http://kgk.gov.tr/DynamicContentDetail/4105/TurkiyeMuhasebeStandartlar\%C4\%B1 (15.08.2018).

https://www.memorial.com.tr/hastane-ve-tip-merkezleri/bahcelievler/ (05.07.2018).

https://oregon.providence.org/location-directory/p/providence-newberg-medical-center/ overview/ (04.07.2018).

http://www.radikal.com.tr/cevre/tbmm-kyoto-protokolune-evet-dedi-920286/ (16.07.2018).

https://www.saglik.gov.tr/TR,11482/enerji-verimliligi.html (03.07.2018).

http://smartecodesign.com/?page_id=1607 (05.07.2018).

http://www.un-documents.net/our-common-future.pdf (16.07.2018). 